\title{
УРОВЕНЬ ЛЕПТИНА И ОСОБЕННОСТИ ЛИПИДНОГО СПЕКТРА КРОВИ У ДЕВОЧЕК-ПОДРОСТКОВ С ОЛИГОМЕНОРЕЕЙ И ВТОРИЧНОЙ АМЕНОРЕЕЙ
}

\section{Д.А. КАШКАЛДА \\ к.биол.н., ведущий научный сотрудник лаборатории \\ возрастной эндокринологии и обмена веществ Института охраны здоровья детей и подростков НАМН Украины, г. Харьков}

\section{С.А. ЛЕВЕНЕЦ}

д.мед.н., профеессор,

руководитель отдела детской гинекологии Института охрань здоровья детей и подростков НАМН Украины, г. Харьков

\section{T.A. НАЧЕТОВА}

к.мед.н., старший научный сотрудник отдела детской гинекологии Института охрань здоровья детей и подростков НАМН Украины, г. Харьков

\section{Т.М. КУЛИНИЧ}

врач-лаборант клинико-

диагностической лаборатории Института охраны здоровья детей и подростков НАМН Украины, г. Харьков
$C$ воевременное выявление и патогенетически обоснованное лечение нарушений менструальной функции, связанных с различными патологическими состояниями репродуктивной системы у девочек-подростков, является важной медико-социальной проблемой. Ее решение тесно связано с программой Европейского регионального бюро ВОЗ «Здоровье для всех в XXI веке». Значимость указанного подтверждается тем, что тяжелые нарушения генеративной функции у взрослых женщин весьма часто являются продолжением или следствием эндокриннозависимых гинекологических расстройств, сорормировавшихся еще в пубертатном периоде [1, 2].

Одним из главных пермиссивных фракторов для полового созревания и поддержания способности организма к репродукции является уровень лептина. Гормон белой жировой ткани лептин не только ответствен за чувство насыщения, но и сигнализирует о достаточном количестве энергии, необходимой для начала процесса полового созревания, оказывает прямое и опосредованное влияние через контроль секреции лютеинизирующего и фолликулостимулирующего гормонов на синтез половых гормонов, регулирует овариальный фолликулогенез [3, 4]. Содержание лептина в крови напрямую зависит от массы тела [5]. Лептин является одним из ключевых регуляторов энергетического гомеостаза организма, воздействуя главным образом на липидный обмен [6, 7], стимулируя окисление жирных кислот, ингибируя липогенез [8, 9].

Исследование взаимосвязи изменений показателей липидного обмена с уровнем лептина в подростковом возрасте, и в частности у девочек, до сих пор остается недостаточно изученной областью гормонально-метаболических взаимосвязей в период становления репродуктивной функции.

В связи с этим целью настоящей работы явилось определение уровня лептина в зависимости от особенностей липидного спектра крови у девочек-подростков с олигоменореей и вторичной аменореей.

\section{МАТЕРИАЛЫ И МЕТОДЫ ИССЛЕДОВАНИЯ}

Обследованы 106 девочек 13-18 лет с вторичной аменореей и олигоменореей, средний возраст которых составил 15,15 $\pm 0,11$ года. В контрольную группу включили 46 девочекподростков того же возраста (средний возраст $15,47 \pm 0,18$ года) с регулярным менструальным циклом и соответствующим возрасту индексом массы тела (ИМТ). ИМТ рассчитывался по формуле Кетле: ИМТ = масса тела (кг) / квадрат величины роста (м) с оценкой полученных результатов по перцентильным таблицам. Девочек контрольной группы обследовали на 5-7-й день менструального цикла.

Содержание лептина в сыворотке крови определяли иммуноферментным методом с помощью набора фрирмы DRG Instruments $\mathrm{GmbH}$ (Германия). Лептинорезистентность (ЛР) рассчитывали по фрормуле: лептин/ИМТ [10]. В сыворотке крови определяли уровень общего холестерина (ОХC), холестерина липопротеинов высокой плотности (ЛПВП), триглицеридов (ТГ) на фротометре Cormay Multi (Польша). Содержание XС в составе липопротеинов низкой плотности (ЛПНП) рассчитывали по формуле: ЛПНП = ОХС - (ЛПВП + ТГ/5); уровень ОХС липопротеинов очень низкой плотности (ЛПОНП) - по формуле: ЛПОНП = ТГ/5; коэффрициент атерогенности (KА) - по формуле: $\mathrm{KA}=(\mathrm{OXC}-$ ЛПВП)/ЛПВП.

Статистическую обработку результатов исследования проводили с помощью пакета программ Statgraphics Plus 5,0. Для оценки достоверности различий использовали критерий Вилкоксона - Манна - Уитни. Корреляционный анализ проводили с помощью коэффициента Спирмена (r).

\section{РЕЗУЛЬТАТЫ ИССЛЕДОВАНИЯ И ИХ ОБСУЖДЕНИЕ}

В таблице 1 представлены значения исследуемых показателей липидного обмена и лептина в контрольной группе. Показатели липидного обмена считали патологическими, если ОХС > 5,0 ммоль/л; ЛПВП < 1,1 ммоль/л; ЛПНП > 3,7 ммоль/л; ЛПОНП > 0,23 ммоль/л; ТГ > 1,2 ммоль/л; КА > 3,0, что совпадает с педиатрическими рекомендациями Национальной образовательной программы по холестерину США (NCEP) [11]. 
При исследовании показателей липидного спектра крови у пациенток с гипоменструальным синдромом (вторичной аменореей и олигоменореей) выявлено повышение уровней ТГ (у 23,6\% лиц), ОХС (у 22,1\%), лПОНП (у $26,4 \%)$, КА (у $11,3 \%$ и и снижение содержания ЛПВП (у 17,0\%) по сравнению с контрольной группой. С учетом полученных результатов было установлено, что 23,6\% девочек с гипоменструальным синдромом имеют дислипидемию IV типа, т.е. повышение содержания ТГ и ЛПОНП при нормальных показателях ЛПНП и ОХC [12]. У 23\% пациенток с вторичной аменореей и олигоменореей была зарегистрирована избыточная масса тела, в т.ч. у 13,8\% ожирение.

При патологических изменениях липидного спектра крови атерогенной направленности характерным для девочек-подростков с гипоменструальным синдромом является достоверное повышение ИМТ (табл. 2). При индивидуальном анализе было установлено, что у пациенток с вторичной аменореей и олигоменореей на фоне измененной липидограммы чаще встречалась избыточная масса тела или ожирение. Так, при высоких уровнях ТГ и ЛПОНП увеличенную массу тела регистрировали в 4 раза чаще, чем при их нормальных значениях, и которая соот-

\begin{tabular}{|c|c|c|}
\hline & & ТАБЛИЦА 1 \\
\hline Показатели & Медиана & $\mathbf{M} \pm \mathbf{m}$ \\
\hline Лептин, нг/мл & 15,01 & $15,40 \pm 1,20$ \\
\hline ЛР & 0,73 & $0,75 \pm 0,05$ \\
\hline ИМТ, кг/м² & 19,82 & $20,48 \pm 0,27$ \\
\hline ОХС, ммоль/л & 4,25 & $4,37 \pm 0,12$ \\
\hline ЛПВП, ммоль/л & 1,35 & $1,40 \pm 0,04$ \\
\hline ЛПНП, ммоль/л & 2,75 & $2,81 \pm 0,12$ \\
\hline ЛПОНП, ммоль/л & 0,14 & $0,15 \pm 0,01$ \\
\hline ТГ, ммоль/л & 0,70 & $0,76 \pm 0,05$ \\
\hline КА & 2,15 & $2,20 \pm 0,10$ \\
\hline
\end{tabular}

вой ткани (в 2-2,5 раза, $\mathrm{p}<0,05)$ регистрировали у девочек-подростков с олигоменореей и вторичной аменореей при умеренной гипертриглицеридемии, повышении содержания ЛПОНП, КА и низком уровне ЛПВП. Причем достоверные изменения содержания лептина отмечали не только по сравнению с группой больных без отклонений в липидном спектре крови, но и в сравнении с уровнем гормона в контрольной группе. Следует подчеркнуть, что при изменениях липидограммы выраженная гиперлептинемия встречалась в 43-67\% случаев. Приведенные результаты свидетельствуют о нарушении фризиологической роли лептина и подчеркивают проатерогенное действие этого гормона [13].

\begin{tabular}{|c|c|c|}
\hline Показатели & n & Медиана \\
\hline ТГ < 1,2 ммоль/л & 81 & 20,0 \\
\hline ТГ > 1,2 ммоль/л & 25 & $25,1^{1,2}$ \\
\hline ОХС < 5 ммоль/л & 85 & 20,6 \\
\hline ОХС > 5 ммоль/л & 24 & 19,3 \\
\hline лПВП < 1,1 ммоль/л & 18 & $28,35^{1,2}$ \\
\hline ЛПВП > 1,1 ммоль/л & 88 & 19,55 \\
\hline ЛПНП < 3,7 ммоль/л & 100 & 20,4 \\
\hline ЛПНП > 3,7 ммоль/л & 9 & 19,3 \\
\hline ЛПОНП < 0,23 ммоль/л & 78 & 20,0 \\
\hline лПОНП > 0,23 ммоль/л & 28 & 19,31 \\
\hline $\mathrm{KA}$ & 94 & 19,8 \\
\hline KA & 12 & $29,6^{1,2}$ \\
\hline
\end{tabular}

ветственно отмечалась в 52,0 $\pm 3,84 \%$ и 50,0 \pm $3,57 \%$ случаев по сравнению с 13,58 $\pm 3,11 \%$ и $11,53 \pm 3,54 \%$ ( $<<0,001)$. В 2 раза чаще избыточная масса тела или ожирение наблюдалась у девочек-подростков с гипоменструальным синдромом и при высоком КА по сравнению с нормальными значениями этого показателя - 32,14 $\pm 5,18$ и 19,23 $\pm 2,62 \%$ соответственно ( $p<0,05)$.

На сегодняшний день доказано, что ИМТ является одним из важнейших составляющих, определяющих концентрацию циркулирующего лептина. Параллельно с повышением ИМТ практически у всех девочек с измененными показателями липидного обмена отмечался высокий уровень лептина (табл. 2). В частности, повышение уровня гормона белой жиро-

\begin{tabular}{|c|c|c|c|c|}
\hline $\mathrm{K} \Gamma / \mathrm{M}^{2}$ & \multicolumn{2}{|c|}{ Лептин, нг/мл } & \multicolumn{2}{|c|}{ ЛP } \\
\hline$M \pm m$ & Медиана & $M \pm m$ & Медиана & $M \pm m$ \\
\hline $20,54 \pm 0,43$ & 13,88 & $18,99 \pm 1,85$ & 0,73 & $0,85 \pm 0,07$ \\
\hline $25,55 \pm 1,52$ & $25,23^{1,2}$ & $29,97 \pm 3,99$ & $0,91^{1,2}$ & $1,10 \pm 0,12$ \\
\hline $21,81 \pm 0,59$ & 15,76 & $22,43 \pm 2,05$ & 0,79 & $0,95 \pm 0,07$ \\
\hline $22,19 \pm 1,39$ & 13,04 & $20,42 \pm 3,34$ & 0,74 & $0,83 \pm 0,08$ \\
\hline $27,77 \pm 1,74$ & 33,232 & $33,55 \pm 5,16$ & 1,092 & $1,12 \pm 0,14$ \\
\hline $20,48 \pm 0,42$ & 14,701 & $19,13 \pm 1,72$ & 0,741 & $0,87 \pm 0,06$ \\
\hline $21,68 \pm 0,53$ & 15,05 & $21,78 \pm 1,81$ & 0,77 & $0,93 \pm 0,06$ \\
\hline $24,23 \pm 3,29$ & 14,83 & $24,34 \pm 7,13$ & 0,77 & $0,87 \pm 0,16$ \\
\hline $20,57 \pm 0,44$ & 13,79 & $18,87 \pm 1,86$ & 0,73 & $0,85 \pm 0,07$ \\
\hline $24,92 \pm 1,42$ & $24,20^{1,2}$ & $29,13 \pm 3,81$ & $0,91^{1,2}$ & $1,09 \pm 0,12$ \\
\hline $20,69 \pm 0,42$ & 14,82 & $19,78 \pm 1,73$ & 0,74 & $0,88 \pm 0,06$ \\
\hline $29,84 \pm 2,12$ & $34,66^{1,2}$ & $35,64 \pm 6,19$ & $1,17^{1,2}$ & $1,13 \pm 0,17$ \\
\hline
\end{tabular}

При повышении концентрации лептина у девочек с гипоменструальным синдромом развивается ЛР, которая проявляется отсутствием адекватного ответа на высокий уровень гормона и может быть обусловлена угнетением синтеза белка, связывающего лептин в крови, а также генетическими мутациями, дефектом в рецепторе лептина или нарушением его транспорта через гематоэнцефалический барьер [14]. Индекс ЛР у пациенток с олигоменореей и вторичной аменореей имел такую же зависимость от изменений липидограммы, как и продукция лептина ( $<<0,05)$. Следовательно, в формировании дислипидемий при нарушениях менструальной функции у девочек определенное значение имеет гиперлептинемия.
ТАБЛИЦА 2. УРОВЕНЬ ЛЕПТИНА У ДЕВОЧЕКПОДРОСТКОВ СО ВТОРИЧНОЙ АМЕНОРЕЕЙ И ОЛИГОМЕНОРЕЕЙ В ЗАВИСИМОСТИ ОТ НАЛИЧИЯ ДИСЛИПИДЕМИЙ $\mathrm{p}<0,05$ по сравнению с низкими показателями липидного обмена $2 \mathrm{p}<0,05$ по сравнению $\mathrm{c}$ контрольной группой 


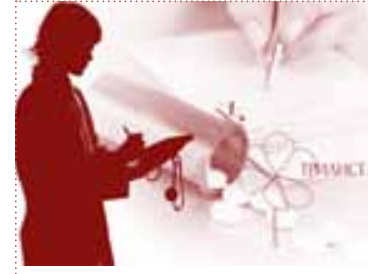

В формировании дислипидемий при нарушениях менструальной функции у девочек-подростков определенное значение имеет повышенное содержание гормона белой жировой ткани лептина
Известно, что гиперлептинемия, ЛР и дислипидемия являются факторами риска формирования метаболического синдрома - одного из самых распространенных в мире заболеваний [15-18]. Обнаруженное повышение уровня лептина, ИМТ и наличие ЛР при дислипидемиях у девочек с гипоменструальным синдромом могут привести к формированию метаболического синдрома и сопряженных с ним заболеваний.

Для оценки взаимосвязей изменений уровня лептина и показателей липидного спектра крови у здоровых пациенток и их сверстниц с нарушениями менструальной функции был проведен корреляционный анализ, в результате которого выявлены некоторые особенности взаимосвязи изученных показателей в рассматриваемых группах. У лиц контрольной группы установлена обратная корреляционная зависимость средней силы уровня лептина и показателя ЛР с ТГ $\left(r_{\text {лептин }}=-0,37 ; p<0,01\right.$ и $r_{\text {лр }}=-0,38$; $p<0,01)$ и ЛПОНП $\left(r_{\text {лептин }}=-0,36 ; p<0,01\right.$ и $\left.r_{\text {лр }}=-0,37 ; p<0,01\right)$. Это косвенно подтверждает данные о фризиологическом эфрфекте лептина, заключающемся в усилении липолиза [19]. Лептин ограничивает накопление ТГ в печени и скелетных мышцах как путем прямой активации, так и опосредованно, через ЦНС [20]. Обнаружена закономерная прямая корреляционная связь между лептином и ЛP ( $r=0,98 ; p<0,001)$, лептином и ИМТ ( $r=0,43 ; p<0,005)$.

У девочек-подростков с вторичной аменореей и олигоменореей связь лептина с ЛР аналогична таковой в контрольной группе ( $r=0,94 ; p<0,001)$, а зависимость между лептином и ИМТ более значима, с большей степенью вероятности ( $r=0,72 ; p<0,001)$. В отличие от контрольной группы при олигоменорее и вторичной аменорее обнаружена зависимость ЛР от ИМТ ( $r=0,48 ; p<0,001)$. Появляются множественные связи ИМТ с показателями липидного спектра крови. Установлена прямая корреляционная зависимость ИМТ от уровня атерогенных липидов: с ТГ ( $r=0,53$; $p<0,001)$, с КА ( $r=0,58 ; p<0,001)$, с ЛПОНП $(r=0,53 ; p<0,001)$. Обратная взаимосвязь наблюдалась с ЛПВП, обладающими антиатерогенными свойствами ( $r=-0,40 ; p<0,001)$. Полученные данные подчеркивают взаимовлияние нарушений показателей липидного обмена и массы тела.

В отличие от лиц контрольной группы при олигоменорее и вторичной аменорее складывались другие взаимосвязи между уровнем лептина и показателями липидного обмена. Так, выявлена прямая корреляционная связь гормона с ТГ $(r=0,36 ; p<0,0001)$, с KA $(r=0,38 ; p<0,0001)$, с ЛПОНП ( $r=0,36$; $\mathrm{p}<0,0001)$. Обнаружена умеренная негативная зависимость между лептином и ЛПВП $(r=-0,36 ; p<0,0001)$. Взаимосвязь аналогичной направленности регистрировали между ЛР и исследуемыми показателями липидного спектра крови. Обнаруженные корреляционные взаимосвязи совпадают с результатами исследований у взрослых женщин. Ряд авторов выявил аналогичную зависимость лептина от показателей липидного обмена при сахарном диабете и ожирении [20, 21].

Таким образом, у девочек-подростков с олигоменореей и вторичной аменореей выраженность атерогенных изменений липидного спектра крови тесно связана с уровнем лептина и ИМТ. Выявленные нарушения липидного спектра крови в сочетании с повышением концентрации лептина, особенно у девочек с ожирением, являются факторами повышенного риска развития атеросклероза и сердечно-сосудистых заболеваний в будущем, что требует своевременной и эффрективной коррекции метаболических изменений.

Результаты данного исследования подтверждают имеющиеся немногочисленные сведения о возможной общности и синергизме уровня лептина, проатерогенных и антиатерогенных механизмов при нарушениях менструальной функции, в т.ч. и у девочекподростков.

\section{Выводы}

1. Характерным для девочек-подростков с гипоменструальным синдромом при патологических изменениях липидного спектра крови атерогенной направленности является повышение ИМТ, в частности избыточная масса тела или ожирение, которые в 2-4 раза чаще встречались именно у больных с измененной липидограммой.

2. У девочек с олигоменореей и вторичной аменореей при дислипидемиях обнаружено значительное повышение уровня лептина и наличие ЛР, причем у половины из них отмечалась выраженная гиперлептинемия.

3. У пациенток с олигоменореей и вторичной аменореей выявлена выраженная положительная корреляционная взаимосвязь между уровнем лептина и ИМТ, лептином и ЛР. Обнаружена прямая зависимость уровня лептина, ЛР и ИМТ от проатерогенных показателей липидного обмена (ТГ, ЛПОНП, КА) и отрицательная - от антиатерогенных (ЛПВП).

4. Выявленные нарушения липидного спектра крови в сочетании с повышением уровня лептина и ЛР, особенно у девочек с избыточной массой тела и ожирением, являются фракторами повышенного риска формирования метаболического синдрома и сопряженных с ним заболеваний в будущем, что требует своевременной и эффрективной коррекции метаболических изменений. 


\section{ЛИТЕРАТУРА}

1. Tremblay L., Frigon J.Y.

The interaction role of obesity and pubertal timing on the psychosocial adjustment of adolescent girls: Iongitudinal data // Int. J. Obes. (Lond). 2005. - Vol. 29, № 10. - P. 1204-1211.

\section{2. Паращук Ю.С., Лісова М.А., Зобіна Л.Ю.}

Реалізація репродуктивного потенціалу в жінок із порушенням менструальної функції в анамнезі // Здоровье женщины. - 2009. - № 8. C. $152-154$

\section{3. Гоженко А.И.}

Роль лептина в фоизиологии и патологии репродуктивной системы // Патология. - 2005. - Т. 2, № 2. - С. 12-16.

\section{Magni $P$.}

Leptin: a possible link between food intake, energy expenditure, and reproductive function // Regul. Peptides. - 2000. - № 92. - P. 51-56.

\section{5. Андреева В.О., Шабанова Л.Ю.}

Тактика ведения девочек-подростков с диссрункцией яичников и избыточной массой тела // Репродуктивное здоровье детей и подростков. - 2011. - № 1. - С. 26-35.

\section{6. Селиванова А.В.}

Лептин и его влияние на энергетический обмен: обзор литературы // Клиническая лабораторная диагностика. - 2005. - № 7. - С. 17-20.

\section{7. Панков Ю.А.}

Новые системы проведения сигналов в механизмах гормональной регуляции // Проблемы эндокринологии. - 2000. - № 4. - С. 3-8.

\section{Minokoshi Y., Kim Y.-B., Peroni O.D. et al.}

Leptin stimulates fatty-acid oxidaition by activating AMP-activated protein kinase // Nature. - 2002. - V. 415 - P. 339-343.

\section{Unger R.H.}

Hyperleptinemia: protecting the heart from lipid overload // Hypertension. 2005. - Vol. 45. - P. 1031-1034.

\section{0. Мадянова Т.С., Мадянов И.В.}

Связь массы тела и менструальной функции у девочек-подростков // Материалы II Национального конгресса терапевтов: Новый курс: консолидация усилий по охране здоровья нации. - Москва, 2007. C. $139-140$

11. US Preventive Services Task Force.

Screening for lipid disordes in children: US Preventive Services Task Force recommendation statement. Pediatrics 2007; 120.

\section{2. Лутай M.I.}

Дисліпідемії: клінічне значення та класифрікації // Нова медицина. 2003. - № 4 (9). - C. 16-21.

\section{3. Шварц В.}

Воспаление жировой ткани. Часть 3. Патогенетическая роль в развитии атеросклероза // Проблемы эндокринологии. - 2009. - Т. 55, № 6. - С. 40-45.

14. Балаболкин М.И., Дедов И.И.

Генетические аспекты сахарного диабета // Сахарный диабет. - 2000. № 1. - C. 2-10.

\section{5. Боцюрко В.І., Костіцька І.О., Бабенко І.Г., Скрипник Н.В.}

Роль лептинорезистентності у розвитку метаболічного синдрому // Ендокринологія. - 2006. - Т. 11, № 1. - С. 64-70.

\section{6. Токарчук Н.І., Тимчук $Є . В .$, Процюк Т.Л.}

Особливості ліпідного обміну та рівня лептину у дітей раннього віку 3 надмірною масою та ожирінням // Современная педиатрия. - 2010. № 2 (30). - C. 127-130.

\section{Biro F.M., Wien M.}

Childhood obesity and adult morbidities // Am. J. Clin. Nutr. - 2010. Vol. 91. - P. 1499-1505.

\section{8. Маліновська Т.М., Большова О.В.}

Метаболічний синдром у дітей та підлітків: особливості клінічного перебігу, показників вуглеводного та ліпідного обміну // ПАГ. - 2011. Т. 73, № 4. - С. 172-177.

\section{9. Залесский В.Н., Великая Н.В.}

Апоптоз адипоцитов и механизмы лептинзависимой регуляции ожирения и избыточной массы тела (состояние, проблемы и перспективы) // Проблеми харчування. - 2004. - № 3. - С. 23-27.

20. Hileman S.M., Pierroz D.D., Masuzaki H. et al.

Characterization of short isoforms of the leptin receptor in rat cerebral microvessels and of brain uptake of leptin in mouse models of obesity // Endocrinology. - 2002. - Vol. 143. - P. 775-783.

21. Светлаков А.В., Яманова М.В., Филиппов О.С., Махалова Н.А. Лептин и липидный спектр крови у женщин с разными типами ожирения // Проблемы репродукции. - 2001. - № 6. - С. 33-36.

22. Мітченко О.І., Романов В.Ю., Яновська К.О. та інші.

Адипокіни та їх співвідношення у хворих з метаболічним синдромом // Український кардіологічний журнал. - 2011. - № 6. - С. 71-78. 